\title{
The past is always present: The image of early Netherlandish art in the long nineteenth century
}

Wilhelm (Guillaume) Koller, Hugo van der Goes painting the portrait of Mary of Burgundy, ca. 1872, oil on panel, $59.4 \times 86.4 \mathrm{~cm}$, New York, The Metropolitan Museum of Art, inv. 81.1.662.
In 1881, the American collector Stephen Whitney Phoenix bequeathed to the Metropolitan Museum of Art in New York a painting by the artist Wilhelm (Guillaume) Koller (18291884/1885) entitled Hugo van der Goes painting the portrait of Mary of Burgundy (fig. 1). Koller, who trained in Vienna and Düsseldorf, moved in 1856 to Belgium, where he exhibited this painting at the Brussels Salon of $1872 .{ }^{1}$ The picture imagines an encounter between Van der Goes (ca. 1440-1482) and Mary of Burgundy (1457-1482), shown as a child seated on the lap of her young stepmother Margaret of York (1446-1503). Behind them is likely Charles the Bold (1433-1477), who married Margaret after the death of Mary's mother, Isabella of Bourbon (1434-1465). ${ }^{2}$ Koller's painting offered nineteenth-century audiences an appealing, if fictional, image of an esteemed northern European artist depicting a moment in the domestic life of a noble dynasty closely identified with the history and heritage of Belgium. ${ }^{3}$

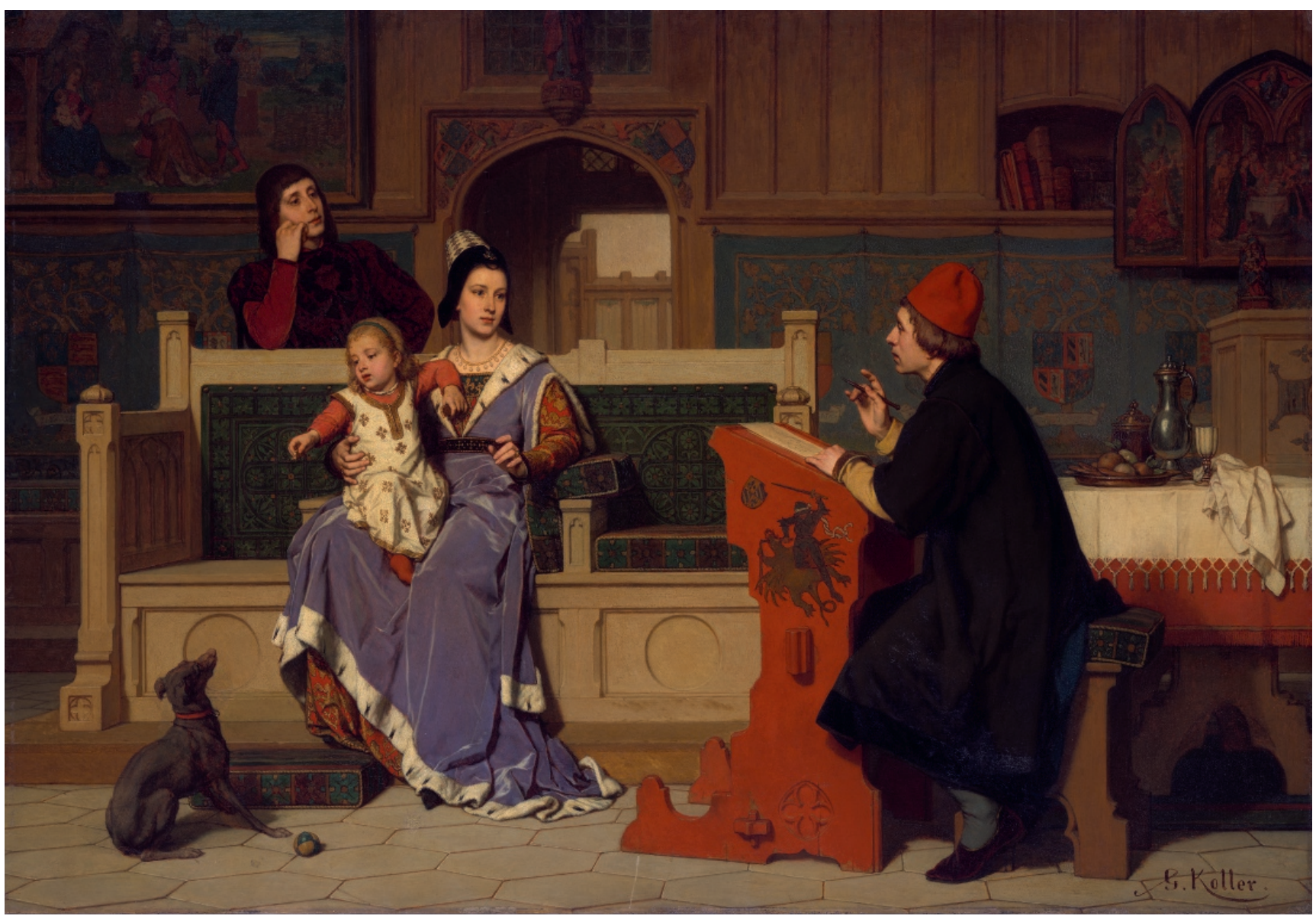


Koller specialized in genre scenes celebrating fifteenth- and sixteenth-century European culture, and particularly that of present-day Belgium, Austria, and Germany. This painting engages directly with what we now call early Netherlandish art, produced between about 1420 to 155 , largely in centers of creativity in the Burgundian, and later Habsburg, Netherlands. In Koller's day, this art historical period was closely identified with the 'Flemish Primitives' and the 'northern Renaissance' - terms with national and ideological implications, as discussed in the next section of this introduction. ${ }^{4}$ Koller's painting raises a set of questions central to this issue of Oud Holland: what sparked the artist's choice of subject? What perceptions of early Netherlandish art and history does the picture convey? What relationship between the early Netherlandish past and Koller's present does the scene imply? The answers to these questions lie in the impulses driving the phenomenon of historic revival in nineteenth-century Belgian art and the concurrent surge of interest in early Netherlandish painting. ${ }^{5}$

In his seminal study History and its images (1993) Francis Haskell argued that the 'rediscovery' of early Netherlandish painting in the long nineteenth century brought to light a corpus of artworks that played a pivotal role in the emergence of new historical discourses, the articulation of contemporary political and cultural ambitions, and the uneasy formation of national identity that characterized the beginnings of the modern Belgian nation-state. ${ }^{6}$ Haskell's study is a lynchpin for a body of scholarship examining the reinvigoration of early modern artistic exemplars in the nineteenth-century Belgian context. ${ }^{7}$ In the wake of Belgium's separation from the Kingdom of the Netherlands and emergence as an autonomous national entity in 1830, the country's leaders promoted an illustrious artistic history as a basis for a common heritage around which the body politic could unite. ${ }^{8}$ There was a great deal at stake in the concept of cultural continuity: the new Belgian nation represented an uneasy marriage of predominantly Flemish-speaking territories in the north and French-speaking territories in the Walloon South, each with its own linguistic and regional identities. ${ }^{9}$

This essential tension was amplified by the pressures of industrialization, urbanization, laissez-faire capitalism, disputes over the role of the Catholic Church in national life, and, beginning in 1885 , colonialism - social fault lines that made a splendid artistic heritage all the more attractive as a rallying point for the young Belgian state. ${ }^{10}$ The symbolic currency of art history could hardly have been higher, and players across the political and cultural spectrum accordingly tried to stake a claim on the art of earlier eras." Their efforts yielded multiple, at times competing, conceptions of the past and its implications for Belgium in the present. ${ }^{12}$

The exploration of this artistic heritage was capacious, extending from the Van Eyck brothers to Rubens. ${ }^{13}$ Yet early Netherlandish painting enjoyed special significance as the 'originary' expression of regional 'genius' that positioned Belgium at the center of an artistic transformation: the purported invention of oil painting by Jan van Eyck (ca. 1390-1441), which enabled a new degree of naturalism, and the beginnings of a northern Renaissance. ${ }^{14}$ The Belgian poet and art critic Émile Verhaeren (1855-1916), contemplating the Ghent Altarpiece, proclaimed that the art of this period was, "like a great painted book, wide open, / enclosing, in its red or blond pages / and in its golden texts, four thousand years of the world: / the entire dream of humanity in the face of the universe .... a grandiose and pure and marvelous poem. ${ }^{15}$

Koller's subject would have resonated in this cultural landscape as an evocation of early Netherlandish artistic genius and its alignment with political and economic power - a vision that dovetailed with the aspirations of the nineteenth-century Belgian state. ${ }^{16}$ In this respect, the picture exemplifies the essential interconnectedness of Belgian nationalism and the early Netherlandish revival. Yet at the same time, this nationalism existed within a complex set of impulses surrounding the 'rediscovery' of early Netherlandish art, which extended well beyond questions of Belgian identity and beyond the nation's borders: the desire for alternatives to artistic conventions seen as 
Print Room, inv. 97314. empty and stale; a new interest in forms of realism; a related esteem for art that seemed to embody simplicity, vitality, and fidelity to nature; and, more broadly, with the assertion of a variety of religious and political agendas and identities. ${ }^{17}$

\section{Inventing early Netherlandish art}

Koller's painting also calls attention to some of the ways in which the nineteenth century gave rise to the concept of early Netherlandish painting as a distinct field of art historical inquiry and continues to shape our understanding of artistic developments north of the Alps in the early modern period. Suzanne Sulzberger's groundbreaking La Réhabilitation des Primitifs flamands: 1802-1867 of 1961 demonstrated how overlapping scholarly, aesthetic and commercial interests raised the profile of this period in art history, and of its leading artists, in the context of European, and particularly German and English, Classicism and Romanticism. At the same time, Sulzberger revealed the cultural, political and nationalist implications of the shifting terminology used to describe this period..$^{18}$

These variances in nomenclature are encapsulated by two exhibitions held in Bruges about thirty years apart. One, in 1867 , was organized by the English scholar W.H. James Weale (1832-1917) under the title Tableaux de l'ancienne école néerlandaise, a construction that closely resembles 'early Netherlandish' painting, the term preferred by more recent scholars, including many of the contributors to the present issue, to refer to art produced before the scission of the Northern and Southern Netherlands in the Dutch Revolt (1566-1648). ${ }^{19}$ The second and more famous exhibition, organized in Bruges in 1902 under the direction of Baron Henri Kervyn de Lettenhove (1856-1928), advertised the artists on view as the 'Primitifs flamands' (fig. 2). The exhibition's coordinators settled on this compound term after much debate. Scholars, including the Belgian patriot Jules Helbig, opposed describing early Netherlandish art as 'primitive' - a concept associated with evolutionary models that nineteenth-century critics had applied to Italian painting before Raphael. ${ }^{20}$ Yet the committee unquestioningly approved the use of 'Flamands', embracing a term that Belgian writers had almost universally adopted to refer to the early rise of independent oil painting and its practitioners. ${ }^{21}$ Although articulated in French, which was then the culturally dominant language in Belgium, the exhibition's title thus emphasized the 'Flemish' origins of the tradition of oil painting. It also helped to propel a nationalist discourse in Belgium that privileged 'Flemish' culture over a more expansive, pan-Netherlandish identity encompassing both the Northern and Southern Netherlands. ${ }^{22}$ As the essays in this issue attest, the term 'Flemish Primitives' still retains a degree of currency, particularly in French scholarship.

The 1902 exhibition marked a turning point in the understanding of early Netherlandish art. ${ }^{23}$ Incorporating multiple media and spanning over a century of artistic production, this major loan exhibition attracted considerable international attention, giving rise to some of the period's most important studies of Netherlandish art and culture, and inspiring exhibitions in cities including Düsseldorf, Paris, and Barcelona. ${ }^{24}$ While the 1902 exhibition sparked a wide range of critiques as well as influential scholarship, it was also hugely important for cementing longstanding rifts in the scholarly and critical reception of early modern art produced in the Low Countries. The German art historian Max Friedländer (1867-1958) emerged from the exhibition with a laudatory view of the legacy of the Van Eycks. In his eyes, these painters and their nearcontemporaries broke with centuries of stagnation by looking to the "infinite diversity" of nature and using their mastery of oil painting technique to examine and depict the world around them — not unlike nineteenth-century concepts of realism. ${ }^{25}$ Friedländer's writings position the Netherlandish tradition as a threshold to artistic modernity, and ascribe to Netherlandish art a positive value that does not depend on Italian ideals of perspective or classical depictions of the body ${ }^{26} \mathrm{His}$ interpretation largely parallels those of contemporaries including Hippolyte Taine and Louis Courajod in France, 


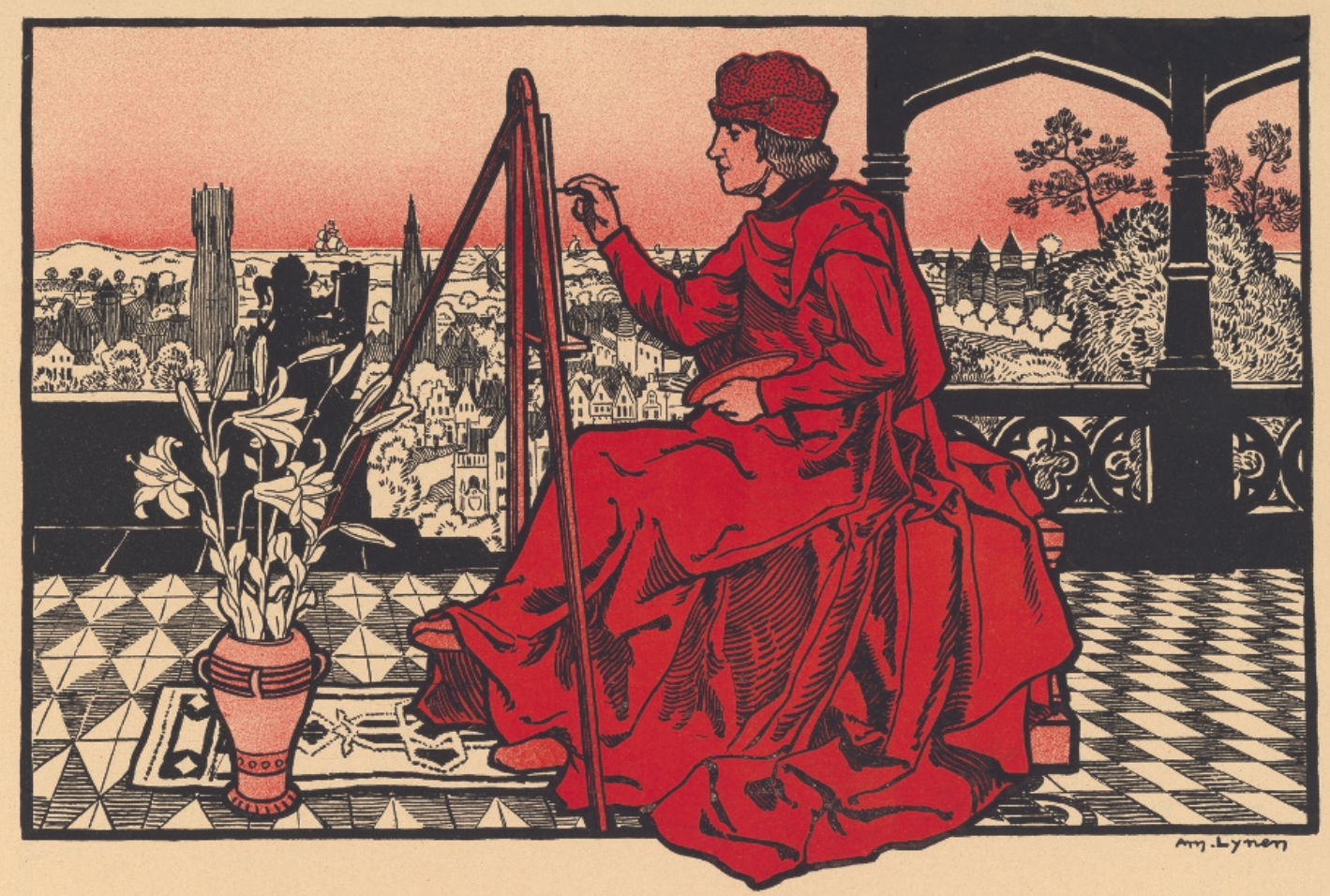

\section{LESPRIMITIFSFLAMANDS à BRUGES}

Exposition de 400 Tableauxde VANEYCKYANDERWEYDEN,MEMLING BOUTS,GERARDDAVID,METSYS etc.

8d'Objets d'Art des XV.8XXVI. Siècles OUVERTE JUSQUAU J5 7 $7^{\text {bre }} 1902$.

Litн. J.L.GofFART BruxelLes 
Karl Voll in Germany, and Hippolyte Fierens-Gevaert in Belgium, all of whom understood early Netherlandish painting as the point of origin for a distinctly northern Renaissance. Friedländer would devote his career to studying this art and developing a multivolume catalogue that remains an essential point of reference. ${ }^{27}$

The Dutch historian Johan Huizinga (1872-1945) responded differently to the 1902 exhibition. ${ }^{28}$ His visit to the show shaped the assessment articulated in The autumn of the Middle Ages, his highly influential yet contentious study of Netherlandish culture, first published in Dutch in 1919. ${ }^{29}$ In that text, he famously identified in the 'naturalism' of the Van Eycks a belated "unfolding of the medieval spirit" in decline. ${ }^{30}$ Where Friedländer invited favorable comparisons to nineteenth-century realism, Huizinga saw the decadence of a premodern society of spectacle focused on ritual performances. ${ }^{31}$ Huizinga's arguments stand apart for their rejection of any explicit connection between the Netherlandish past and contemporary Dutch or Belgian culture - a prevailing view advanced by his influential Belgian contemporary Henri Pirenne..$^{32}$ Yet Huizinga's determined resistance to seeing a modernist-realist character in early Netherlandish art is a measure of just how successful his nineteenth-century predecessors were in establishing the terms on which this art was exhibited, studied, and invoked as a common heritage for modern Belgian society. ${ }^{33}$ Both Friedländer's and Huizinga's projects reflect the ways in which nineteenth-century understandings of the past shaped the historiography of early Netherlandish art as a site of contested significance. The 'rehabilitation' of the masters that culminated in the 1902 exhibition was, ultimately, a deeply political effort, enmeshed in debates about how (or if) the Netherlandish past could be brought to bear on Belgian culture in the present and appropriated in other contexts for specific ideological purposes.

\section{The past is always present}

It is the intersection of artistic and art historical practice in the long nineteenth century, and its enduring impact on the development of early Netherlandish art history as a field of study, that inspired this issue of Oud Holland, which originated as a panel held at the Historians of Netherlandish Art conference in Ghent in 2018. The essays examine the myriad ways in which, to quote the Belgian playwright and poet Maurice Maeterlinck, "the past is always present". ${ }^{34}$ They are concerned with the study, creative adaptation, reception, and active promotion of early Netherlandish art, in particular painting, in Belgium, and in England and German-speaking regions that took a keen scholarly and political interest in their young neighbor. ${ }^{35}$ The essays address varied aspects of this cultural and intellectual landscape: art historical writing and exhibitions; architecture and design; painting and drawing; and photography. Collectively, the authors illuminate how the past and the present were brought into productive interplay through a range of interconnected practices.

The essays form three thematic pairs, each highlighting a different facet of the nineteenth-century engagement with early Netherlandish art. The section Documenting the past considers the deeper meanings of attempts to record and preserve the Belgian artistic heritage. Sandra Hindriks presents a case study on the impact of nationalist agendas on art historical interpretation. Examining a ceremonial goblet presented to the Antwerp painters' guild of St Luke in 1549 but now destroyed, she explores how nineteenth-century views of the city's artistic heritage may have given rise to a significant mistake in identifying one of the figures portrayed on the precious object as Jan van Eyck, rather than Raphael. Correcting this error, and the historiography to which it gave rise, she exposes how nineteenth-century historians in Antwerp constructed an artistic history with more explicitly nationalist or regionalist claims than their early modern forebears, whose more international outlook has only recently begun to receive scholarly attention..$^{6}$ 
Érika Wicky's contribution revisits photography's role in establishing the early Netherlandish canon. Her investigation into Belgian photographer Edmond Fierlants' state-sponsored project to create highly detailed reproductions of early Netherlandish paintings elucidates the vital part played by photography in enabling connoisseurship. Wicky's essay also highlights perceived technical and aesthetic parallels between centuries-old paintings and the very modern medium of photography, which, advocates argued, made it uniquely suitable to the task of documenting and promoting early Netherlandish art.

Appropriating the past analyzes creative borrowing and reuse as strategies for bringing early Netherlandish painting to bear on the concerns of the present. Douglas Brine examines a set of drawings by Augustus Welby Northmore Pugin now in the Metropolitan Museum of Art, New York and Yale University's Beinecke Library, revealing how the distinctive vocabulary of forms that shaped Pugin's architectural practice in Victorian England was rooted in his study of Netherlandish art in private English collections, in printed reproductions, and through travel to the Low Countries. ${ }^{37}$ Brine demonstrates how Pugin tapped into the perceived religiosity of early Netherlandish art to market designs specifically to English Catholic patrons.

Susan Canning explores the artist James Ensor's ironic mode of citing and co-opting the Netherlandish past. Adopting the critical lens of 'flandricism', the linguistic practice of intermingling Flemish idioms in French texts, she considers how Ensor used pictorial references to Flemish and Netherlandish art and history to express his own artistic and cultural identity, and critique contemporary Belgian society and politics. In a culture that took its art and history very seriously indeed, Ensor's irreverent and satirical approach to the exalted exemplars of the past, stands out as a marked counterpoint and site of resistance.

Interpreting the past brings together two essays that examine the important role of German art historians in shaping an international image of Netherlandish art. Henrik Karge examines Karl Schnaase's Niederländische Briefe (Letters from the Netherlands), published in 1834 - a heterogeneous volume of travel writing, personal reflections, and extensive discussions of art. By providing a close reading of a selection of passages discussing art in the Low Countries, Karge demonstrates how Schnaase developed an identity for Netherlandish art in contradistinction to Italian traditions. In doing so, he advanced an early form of comparative art history for Netherlandish painting, mapping a synthetic history of the development of art by peoples and cultures decades before such practices crystalized in academic discourse.

William Diebold examines a text written by Paul Clemen, the curator of the 1904 exhibition in Düsseldorf of paintings from the Rhineland, which came on the heels of the 1902 exhibition in Bruges. Diebold demonstrates how Clemen's musings on his era's preference for 'primitive' art of the fifteenth and sixteenth centuries contravene explanations of that predilection as a product of nationalism and artistic modernism. Diebold identifies other associations of this art, which emerge, explicitly and implicitly, in Clemen's text, including its gendered connotations and its conservative appeal to notions of piety, craft, tradition, and community in opposition to ideals of progress and modernity.

Diebold's essay is an apt conclusion to this issue. Standing on the threshold of a new century, Clemen was able to cast a critical eye over the resurgent interest in early Netherlandish art in prior decades. He began to explore the nature of the field's appeal, working through its multiple and sometimes divergent significations, and, perhaps most importantly, expressing an incipient recognition that the tastes and the concerns of the present conditioned understanding of the artistic past. 


\section{ABOUT THE GUEST EDITORS}

Alison Hokanson (1979) is Associate Curator for nineteenth-century European painting at the Metropolitan Museum of Art, New York, where she has curated exhibitions on the art and design of the Pre-Raphaelites and on the paintings of Joseph Mallord William Turner. In addition to her exhibitionrelated publications, she has recently published essays on the interior scenes and landscapes of the Belgian realist painter Henri De Braekeleer (1840-1888). She received her MA and PhD from the Institute of Fine Arts, New York University.

Edward H. Wouk (1980) is Reader in Northern Renaissance Art in the Department of Art History and Cultural Practices at the University of Manchester (UK). His recent publications include Frans Floris (1519/20-1570): Imagining a northern Renaissance (Brill, 2018); a volume of essays, co-edited with Suzanne Karr Schmidt, Prints in translation (1450-1750): Image, materiality, space (Routledge, 2017); and the exhibition catalogue Marcantonio Raimondi, Raphael and the image multiplied (Manchester University Press, 2016). He is currently preparing a critical edition of Dominicus Lampsonius' Life of Lambert Lombard (1565) for the Getty's Texts \& Documents series.

\section{NOTES}

1 On Koller's art and career, see J. Dafforne, 'Modern painters of Belgium: No. XI.-Guillaume Koller', The Artjournal, new series 6 (1867), pp. 9-11; 'Koller, Wilhelm', in Österreichisches biographisches Lexikon 1815-1950, vol. 4, Vienna 1969, p. 9o. Koller exhibited two paintings at the Brussels Salon in 1872 , both of which celebrated Belgium's noble past. $\mathrm{Nr} 423$ showed the German merchant Anton Fugger (1493-156o) and Charles V, Holy Roman Emperor (1500-1558). Nr 424 was 'Hugues van der Goes, reçu par la duchesse Marguerite d'York, seconde (sic) femme de Charles le Téméraire, fait le portrait de Marie de Bourgogne', see Exposition générale des Beaux-Arts 1872: Catalogue explicatif, Brussels 1872 , p. 53. The identification of this work as the one now in The Met is supported by J.D. Champlin, Jr. (ed.), Cyclopedia of painters and paintings, vol. 2, New York 1927 (orig. 1886), p. 403, who describes The Met's painting as Hugo van der Goes painting [the] portrait of the infanta Maria de Bourgogne. The armorials in the background of the scene are approximations of the coats of arms of England and Burgundy in the period. The paintings in the background have not been identified it is possible that Koller invented them.

2 Keen-eyed readers will note that Koller exercised some creative license: Margaret of York married Charles the Bold in 1468, when Mary of Burgundy was eleven, much older than the child in the painting. Given that Koller's title in the 1872 exhibition catalogue incorrectly identifies Margaret of York as Charles the Bold's second wife (she was actually his third, and Isabella of Bourbon was his second), the artist may not have had access to the correct facts, or may simply have gotten them wrong. In any case, no records exist of a Van der Goes portrait of Mary of Burgundy at any age. On the reception of Hugo van der Goes in the nineteenth century, see D. Wolfthal, 'Hugo van der Goes: A historiographical study', Center 26 (20052006), pp. 165-167, which discusses Émile Wauters' The painter Hugo van der Goes at the Rode Klooster (Brussels, Musées royaux des Beaux-Arts de Belgique, inv. 2519), also exhibited at the Brussels Salon in 1872, $\mathrm{nr} 873$.

3 Mary of Burgundy's marriage in 1477 to Maximilian of Austria (1459-1519), encouraged by her stepmother, was a politically transformative union that aligned the Burgundian State with the Habsburgs and initiated an enduring French-Habsburg breach. We are grateful to Maryan Ainsworth, Jan Dirk Baetens, Douglas Brine, and Diane Wolfthal for their insights into The Met's painting.
4 See L. Deam, 'Flemish versus Netherlandish: A discourse of nationalism', Renaissance quarterly 51 (1998), pp. 1-33

5 For scholarship on nineteenth-century historic revival in European contexts, see S. Bann, The clothing of Clio: A study of the representation of history in nineteenthcentury Britain and France, New York 1984; D. Lowenthal, The past is a foreign country, Cambridge 1985; M. Chase and C. Shaw (eds.), The imagined past: History and nostalgia, Manchester 1989; and J.B. Bullen, The myth of the Renaissance in nineteenth-century writing, Oxford 1994. Recent studies have also elucidated specific national contexts for revival, see M.J. Lewis, The politics of the German Gothic revival: August Reichensperger, New York 1993; R. Pavoni (ed.), Reviving the Renaissance: The use and abuse of the past in nineteenth-century Italian art and decoration, Cambridge 1997; V. Brand (ed.), The study of the past in the Victorian age, Oxford 1998; E. Emery and L. Morowitz, Consuming the past: The medieval revival in fin-de-siècle France, Aldershot 2003; and L. Bolzoni and A. Payne (eds.), The Italian Renaissance in the 19th century: Revision, revival and return, Milan 2017.

6 F. Haskell, 'Huizinga and the "Flemish Renaissance", in F Haskell, History and its images: Art and the interpretation of the past, New Haven 1993, pp. 431-495.

7 E.g. L. Pil, "The metropolis reviewed: The creation of a golden age', in J. van der Stock (ed.), Antwerp, story of a metropolis: 16th-17th century, Ghent 1993, pp. 129-137; L. Pil, 'Painting at the service of the new nation state,' in K. Deprez and L. Vos (eds.), Nationalism in Belgium: Shifting identities, 1780-1995, London 1998, pp. 42-50; P. Verbraeken e.a., Après \& d'après Van Dyck: La récupération romantique au XIXe siècle, Antwerp 1999; A. Ogata, Art Nouveau and the social vision of modern living: Belgian artists in a European context, New York 2001; H. Todts, "Make way for the old ones! Respect defunct schools!" Ensor and the art-historical canon', in A. Swinbourne e.a., James Ensor, New York 2009, pp. 118-127; J.D. Baetens, '(In) the spirit of the time: Imitation of epochal style in nineteenth-century French and Belgian art,' Nineteenth-century contexts 33 (2011), pp. 209-226; J.D. Baetens, 'For king and country: A new reading of the mural paintings of Henri Leys in the Antwerp city hall', Revue belge de philologie et d'histoire / Belgisch tijdschrift voor philologie en geschiedenis 9o (2012), pp. 513-540. 
8 The fundamental study of this European phenomenon remains B. Anderson, Imagined communities: Reflections on the origin and spread of nationalism, London 1983.

9 The Belgian elite spoke French and were guided by French cultural exemplars. Flemish language (and, to a certain extent, culture) only gained gradual official recognition. On Belgium's regional and linguistic identities and their nationalist implications, see Deprez 1998 (note 7), pp. 51-71, 83-118, 139-152. For the early modern context, see A. Duke, 'The elusive Netherlands: The question of national identity in the early modern Low Countries on the eve of the Revolt', Bijdragen en mededelingen betreffende de geschiedenis der Nederlanden 119 (2004), pp. 10-38. See also Susan Canning's essay in this issue.

10 On the social context for nineteenth-century Belgian art see Art \& societé en Belgique: 1848-1914, Charleroi 1980; A. Murphy and C. Strikwerda, 'Brussels and the Belgian avant-garde in historical and geographical perspective', in S. Goddard (ed.), Les XX and the Belgian avant-garde Prints, drawings, and books ca. 189o, Lawrence 1992; C. Strikwerda, A house divided: Catholics, socialists, and Flemish nationalists in nineteenth-century Belgium, New York 1997; and Deprez 1998 (note 7).

11 The notion of symbolic currency employed here is indebted to Pierre Bourdieu's concept of cultural capital, see P. Bourdieu, 'The forms of capital', in J. Richardson (ed.), Handbook of theory of research for the sociology of education, Greenwich 1986, pp. 241-258.

12 See note 7

13 It even encompassed Dutch painters such as Vermeer, see A. Hokanson, The soul of solemn places: The interior scenes of Henri De Braekeleer (1840-1888), Ph.D. diss. New York University 2013, 'The Netherlandish interior', pp. 106-161.

14 See the critiques of the term 'northern Renaissance' in S. Porras, Art of the northern Renaissance: Courts, commerce and devotion, London 2018, pp. 10-13; E. Wouk, Frans Floris (1519/20-1570): Imagining a northern Renaissance, Leiden 2018, spec. p. 13. The term 'genius' as used here refers to the concepts of individual genius and collective genius of place (genus loci) as articulated in ancient sources and examined in eighteenth- and nineteenth-century philosophy and letters. Of the vast literature on the subject, see P. Murray (ed.), Genius: The history of an idea, Oxford 1989; C. Norberg-Schulz, Genius loci: Towards a phenomenology of architecture, New York 1980.

15 "Comme un grand livre peint et largement ouvert, / Elle enfermait, en ses pages rouges ou blondes / Et dans ses textes d'or quatre mille ans du monde: / Tout le rêve de l'homme en proie à l'univers. / L'œuvre dardait dans l'art une clarté suprême. / Comme celle du Dante à Florence, là-bas,/ Mais cette fois deux noms flamands brillaient, au bas / Du grandiose et pur et merveilleux poème.", see E. Verhaeren, Les héros, Brussels 1908, 'Les Van Eyck', pp. 51-54. The full text of the poem underscores the appeal of early Netherlandish art as a manifestation of piety in predominantly Catholic Belgium. We are grateful to Douglas Brine for his thoughts on this topic. On Verhaeren's writings on the northern Renaissance, see É. Verhaeren, Essays on the northern Renaissance, A. Alhadeff (trans.), New York 2012

16 On these aspirations, see Pil 1993 (note 7); S. Goddard 'Investigating and celebrating the 'golden age' in nineteenth-century Antwerp: 1854-1894,' in L.S. Dixon (ed.), In detail: New studies of northern Renaissance art in honor of Walter S. Gibson, Turnhout 1998, pp. 151-164.

17 On the broad international appeal of early Netherlandish painting, see E. Fahy, 'How the pictures got here', in M. Ainsworth and K. Christiansen (eds.), From Van Eyck to Bruegel: Early Netherlandish painting in the Metropolitan Museum of Art, New York 1998, pp. 63-75; G. Tinterow and P. Conisbee (eds)., Portraits by Ingres: Images of an epoch, New York 1999, pp. 68-71; J. Graham. Inventing Van Eyck: The remaking of an artist for the modern age, New York 2007; Baetens 2011 (note 7); A. Smith e.a., Reflections: Van Eyck and the Pre-Raphaelites, London 2017; S. AveryQuash,"Pre-Van Eycks": The influence of early

Netherlandish and German art on the Pre-Raphaelites', in M. Buron, Truth and beauty: The Pre-Raphalites and the old masters, San Francisco 2018, pp. 31-38.

18 S. Sulzberger, La rehabilitation des Primitifs flamands: 1802-1867, Brussels 1961, pp. 44-79.

19 The currency of this term was further crystalized for English readers in E. Panofsky, Early Netherlandish painting: Its origins and character, 2 vols., Cambridge, Mass. 1966. See also J. Chapuis, 'Early Netherlandish painting: Shifting perspectives', in Ainsworth 1998 (note 17), pp. 3-21.

20 Sulzberger 1961 (note 18), pp. 14-20; Haskell 1993 (note 6) pp. 445-468; A. Hayum, 'The 1902 exhibition, Les Primitifs flamands: Scholarly fallout and art historical reflections', Journal of art historiography 11 (2014), pp. 1-20, spec. 11-12. For a diversity of views on the concept of primitivism in this period, see C. Rhodes, Primitivism and modern art, New York 1994; L. Jessup (ed.), Antimodernism and artistic experience: Policing the boundaries of modernity, Toronto 2001; E.H. Gombrich, The preference for the primitive: Episodes in the history of Western taste and art, London 2002; Emery 2003 (note 5), ch. 2; L. Morowitz, 'Primitive', in E. Emery and R. Utz (eds.), Medievalism: Key critical terms, Cambridge 2014, ch. 22; P. Dagen, Primitivismes: Une invention moderne, Paris 2019. On the evolutionary connotations of the term in this context, see A. Hokanson, 'Henri De Braekeleer and Belgium's nineteenth-century revivalist movement', in A. Lepine e.a. (eds.), Revival: Memories, identities, utopias, London 2015, pp. 135-149, spec. 144-145. It is noteworthy that Lionello Venturi, one of the most important scholars of the Italian 'primitivi', visited the 1902 Bruges exhibition, see L. Venturi, Il gusto dei primitivi, Bologna 1926, and the important critical study of M. Aguirre, 'From imitazione to creazione: Lionello Venturi, Medieval art, and fascism', Convivium 4 (2017), pp. 88-103.

21 Sulzberger 1961 (note 18), pp. 14-20. Although few of the artists exhibited were actually from Bruges or even the historic county of Flanders, Amédée Lynen's official poster for the exhibition (fig. 2) stressed the connection between this artistic tradition and the quintessentially Flemish, Burgundian city, which appears as the backdrop to, and cradle for, the Eyckian revolution. The poster's design also reflected the aim of attracting tourists to Bruges, which had refused to lend its paintings to Brussels when the exhibition was initially planned to take place there, in part for fear of losing visitors. See Haskell 1993 (note 6), pp. $445-446$.

22 Deam 1998 (note 4), pp. 13-15. On the Great-Netherlandish movement, which dismissed the Belgian state as an artificial diplomatic construction, see J. Tollebeek, 'Historical representation and the nation-state in Romantic Belgium (1830-1850)', Journal of the history of ideas 1998 (59), pp. 329-353, spec. 332, with further references. On language and identity in Belgium during the long nineteenth-century, see note 9

23 Haskell 1993 (note 6), pp. 461-468; Hayum 2014 (note 2o), passim.

24 Haskell 1993 (note 6), p. 445; Hayum 2014 (note 20), p. 13, with further references. 
25 W. Krul, 'Realism, renaissance and nationalism', in B. Ridderbos e.a. (ed.), Early Netherlandish paintings: Rediscovery, reception and research, Amsterdam 2005, pp. 252-289.

26 Krul 2005 (note 25), pp. 256-257, situating Friedländer's views in relation to Jacob Burckhard's hugely influential Civilization of the Renaissance in Italy of 1860.

27 M. Friedländer, Die altniederländische Malerei, Berlin 1924-1937, trans. by H. Norden, Early Netherlandish painting, 14 vols., Leiden 1967.

28 Haskell 1993 (note 6), pp. 468-495; see also J. Huizinga, 'My path to history', in P. Geyl e.a. (ed.), Dutch civilization in the seventeenth century, New York 1968, pp. 266-267.

29 The original title in Dutch is Herfsttij der Middeleeuwen, which was rendered as The waning of the Middle Ages in the original, 1924 English translation, produced with Huizinga's authorization, but later re-translated as The autumn of the Middle Ages in a new critical version based on Huizinga's first and second (1921) editions of the text and earlier translations into German, as cited in note 3 o. See P. Arnade and M. Howell, 'Introduction', in P. Arnade e.a. (ed.), Reading Huizinga: Autumn of the Middle Ages, a century later, Amsterdam 2019.

30 J. Huizinga, The autumn of the Middle Ages, trans. R. Payton and U. Mammitzsch, Chicago 1996, p. 319. See also M. Boon, 'Another failed state', in Arnade 2019 (note 29), pp. 105-122.

31 Huizinga's interest in spectacle has generally been discussed in relation to his study of early modern play, Homo ludens, see D. Penner, Rethinking the spectacle: Guy Debord, radical democracy, and the digital age, Vancouver 2019, pp. 89-9o. Brussels 1902.

33 On reactions to his work specifically in the field of art history, see D. Wolfthal, 'Art history and Huizinga's Autumn of the Middle Ages', in Arnade 2019 (note 19), pp. 123-141.

34 M. Maeterlinck, Le temple enseveli, Paris 1902, p. 205 : "Le passé est toujours présent."

35 Tollebeek 1998 (note 22), pp. 335-336. Writings by German and English scholars and critics played an important part in supporting Belgium's independence and bolstering its national awareness as a bulwark against French power and cultural predominance.

36 Important studies that have stressed early modern Antwerp's internationalism in the visual arts include the exhibitions L. Voet (ed.), Antwerp, the golden age: The rise and glory of the metropolis in the sixteenth century, Antwerp 1973; Van der Stock 1993 (note 7), as well as the essays in B. Ramakers (ed.), Understanding art in Antwerp: Classicizing the popular, popularizing the classic (15401580), Leuven 2011; R. Esser, 'The diamond of the Netherlands: Histories of Antwerp in the seventeenth century', Nederlands kunsthistorisch jaarboek 64 (2014), pp. 348-369. See also K. Jonckheere, 'An allegory of artistic choice in times of trouble: Pieter Bruegel's Tower of Babel', Nederlands kunsthistorisch jaarboek 64 (2014), pp. 186-213; Wouk 2018 (note 14).

37 For a recent comparative study of the formation of national histories and identities in the nineteenth century in the Low Countries and Britain, see H. Dunthorne and M. Wintle (eds.), The historical imagination in nineteenthcentury Britain and the Low Countries, Leiden 2013

\section{PHOTO CREDITS}

Metropolitan Museum of Art, New York (1); Royal Library (KBR), Print Room (2).

\section{SUMMARY}

This special issue of Oud Holland offers new perspectives on the 'rediscovery' of early Netherlandish art in the long nineteenth century. It probes the intersection of creative and scholarly practices that helped to establish the importance of this corpus of artwork, produced between about 1420 to $155^{\circ}$ in the Burgundian (and later Habsburg) Low Countries, and to secure its status as a cultural landmark and a distinct field of art historical inquiry. Investigating topics ranging from Karl Schnaase's pioneering writings, to Augustus Welby Northmore Pugin's influential designs, to James Ensor's radically unconventional imagery, the six essays in this volume explore specific cases in the appropriation, reception, interpretation, and promotion of early Netherlandish art - particularly painting - in a range of cultural practices and circumstances. Topics addressed include art criticism and exhibitions, architecture and design, painting and drawing, and the emergence of 'reproductive' photography.

The essays expand upon such foundational studies as Francis Haskell's History and its images (1993), which demonstrated how the surge of interest in the work of the Van Eyck brothers and their compatriots was inextricable from the evolving national identity and cultural politics of the modern nation-state of Belgium. While the Belgian context is central, several contributors enlarge the scope of inquiry with projects rooted in England and German-speaking regions, which forged strong intellectual and political ties with Belgium and engaged enthusiastically with its artistic heritage. Collectively, the essays advance new insights into the evolution of art history as a discipline, the complexity of artistic modernism(s) and revivalism(s); the role of nationalism and religion in nineteenth-century cultural life; and some of the myriad ways in which the artistic past and present inflect one another. 